\title{
Assess the Level of Occupational Stress and to Evaluate the Effectiveness of Planned Teaching Programme on Knowledge Regarding Occupational Stress and Its Management among Security Guards of a Selected Organization, Shimoga, Karnataka
}

\author{
M. Siddesh ${ }^{1}$, H. N. Ravindra ${ }^{2}$ \\ ${ }^{1}$ Sumandeep Vidyapeeth, Vadodara, Gujarat, India \\ ${ }^{2}$ Sumandeep Nursing College, Sumandeep Vidyapeeth, Vadodara, Gujarat, India \\ Email: siddeshm4@gmail.com
}

How to cite this paper: Siddesh, M. and Ravindra, H.N. (2020) Assess the Level of Occupational Stress and to Evaluate the Effectiveness of Planned Teaching Programme on Knowledge Regarding Occupational Stress and Its Management among Security Guards of a Selected Organization, Shimoga, Karnataka. Open Journal of Nursing, 10, 87-100.

https://doi.org/10.4236/ojn.2020.102005

Received: October 17, 2019

Accepted: January 28, 2020

Published: January 31, 2020

Copyright $\odot 2020$ by author(s) and Scientific Research Publishing Inc. This work is licensed under the Creative Commons Attribution International License (CC BY 4.0).

http://creativecommons.org/licenses/by/4.0/

\section{(c) (i) Open Access}

\begin{abstract}
Background and aim: Occupational stress occurs when there is a disequilibrium between job demands and capabilities. Being employed as a security guard exposes the subject to potentially dangerous situations. Security guards are engaged in a profession that confronts violators of the law as well as violence and thus are more likely to be exposed to traumatic experiences. So it is very important to assess the level of stress they possess and make them aware of the harmful effects and how to manage it. Hence, there is a need to assess the level of occupational stress and to evaluate the effectiveness of PTP on knowledge regarding occupational stress and its management among security guards of a selected organization, Shimoga, Karnataka. Results: Demonstrated that the majority of the security guards were having a moderate level of occupational stress. Among 80 security guards, 59 (74\%) were having a moderate level of occupational stress, $21(26 \%)$ were having a severe level of occupational stress and none of them possessed a mild level of occupational stress. Conclusion: This study contributes to the emerging body of knowledge about occupational stress in their security profession and it is important to plan the healthy coping strategies to cope up with their occupational stress.
\end{abstract}

\section{Keywords}

Occupational Stress, Security Guards, Planned Teaching Programme 


\section{Introduction}

Stress is a physical or emotional state of reaction, always present in all the persons as a result of living on the earth. It is a result of a non specific reaction to internal or external environmental changes or dangerousness. Stress is the black plague of the eighties major problems of everyday routine life, harming individual persons, working place and societal health [1].

Stress has become a common factor in most of all the profession, starting from an artist to a surgeon, or a commercial pilot to a sales executive. Job stress gives rise to an adverse effect on health and performance [2].

Job stress is recognised worldwide as a major challenge to employee's health and the healthiness of their working organisations. WHO is predicting that by 2020 , stress will be a major cause of workplace ill-health [3]. It is now generally accepted that chronic or acute stress can have a negative impact on an individual's mental and physical health. According to the Health Service Executive (HSE), around half a million people in the UK experience work-related stress at a level that they believe is making them ill, up to five million people feel very or extremely stressed by their work and work related stress costs society about $£ 3.7$ billion each year [3].

A survey was conducted by The Regus Business Tracker, a global economic indicator which included over 3 lakh employees from 13 countries and assessed their level of occupational stress. The stress measured from 12,000 employees from India was about 57\% [4].

Occupational stress occurs when there is an imbalance between the demands of the workplace and an individual's ability to carry out and complete the organizational demand. Often a stressor can lead the body to have a physiological disturbance which in turn will result in a strain on a person physically as well as mentally [5].

Occupational stress is often caused because of many reasons among those, it may be because of an increased workload, [6] delegating additional work for the current work, allotting less time span for the completion of the allotted task, expansion working time, paying fewer wages for the work, lack of motivation in an organization [7]. The workplace factors can cause stress like psychosocial factors, in terms of "interactions between and among work environment, job content, organizational conditions and workers' capacities, needs, culture, personal extra-job considerations that may, through perceptions and experience, influence health, work performance and job satisfaction". A negative interaction between occupational conditions and human factors may lead to emotional disturbances, behavioural problems, biochemical and neuro-hormonal changes, presenting added risks of mental or physical illness. On the contrary, when working conditions and human factors are in balance, work creates a feeling of mastery and self-confidence; increases motivation, working capacity and satisfaction; and improves health [8].

Being employed as a security guard continuous exposure to potential threat is 
stressful. In addition, the nature of their work puts physical strain on their bodies that contributes to the manifestation of stress. Security guards are frequently faced with having to-police people, which can lead to conflictual encounters that promote stress. Security guards are engaged in a profession that confronts violators of the law as well as violence and are thus are more likely to be exposed to traumatic experiences [9].

Stress management training, workshops reduce the prevalence of employees with a poor understanding of the principles of the management of stress, and with poor Coping strategies [10].

Study suggest that the intervention is effective in easing occupational stress for high-stress workers [11].

Therefore, its important that giving planned teaching programme on knowledge regarding occupational stress and its management for security guards.

\section{Methods}

\subsection{Participants}

Convenience sample (Target population) consisted of 80 security guards, who work in Hi-Tech Security Services, Shimoga, an organization which recruits security. Inclusion criteria set for sample selection were as follows: Security guards who are willing to participate in the study, who can understand English or Kannada, and Exclusion criteria set is, who are previously sensitized to any research studies since 3 months regarding occupational stress and its management, who are physically not fit.

\subsection{Instruments}

The investigator constructed the tool to collect the background data of the study subjects to identify the association between pre test level of knowledge score and demographic characteristics. It consisted of 11 items, which comprised of age of the participant, sex of the participant, religion, area of living, monthly income, educational qualification, marital status, years of experience, number of working hours per day, number of night shifts per week, and history of any illnesses.

\section{Job stress scale}

Job stress scale was used to assess the occupational stress of the security guards. The job stress scale consisted of 25 items and measured on a 4 point scale. The occupational stress of security guards will be graded into mild, moderate and severe depending on the total score.

The minimum total score will be 0 and maximum will be 75 .

\section{Grading of scores}

\begin{tabular}{ccc}
\hline S1 No. & Score range & Category \\
\hline 1. & $1-25$ & Mild \\
2. & $26-50$ & Moderate \\
3. & $51-75$ & Severe \\
\hline
\end{tabular}


The Cronbach's alpha was caluaulated for these questionnaires with 0.91 which is strongly reliable.

\subsection{Procedure}

This study was approved by the administration of Hi Tech security services. The security guards were informed of the purpose the study, and that they had the right to refuse to participate. Also, the voluntary nature of participation was informed as well as confidentiality, finally, all participants signed for informed consent

\subsection{Data Analysis}

The quantitative data were entered and analyzed using statistical package for social sciences, version 23, Demographic variables were analyzed using frequency and percentage, Level of occupational stress were analyzed using frequency and percentage, Pre-test and post-test level of knowledge were analyzed using mean and Standard Deviation, Effectiveness of planned teaching programme were assessed using paired t test, Association between level of occupational stress and demographic variables were computed using Chi square test.

\section{Results}

The majority of samples that is $33(41.3 \%)$ are in the age group of $30-39$ years, 8 $(10 \%)$ are in the age group of $\geq 50$ years, $30(37.5 \%)$ are in the age group of 40 49 years, and $9(11.2 \%)$ are in the age group of 20 - 29. Based on Gender classification, majority of the samples that is, 54 (67.5\%) were men and $26(32.5 \%)$ were women in the study. Most of the samples 33 (41.2\%) belonged to the Christian community, 17 (21.3\%) were from the Muslim community and 30 (37.5\%) belonged to the Hindu community.

Majority of the samples 45 (56.25\%) are living in urban area and 35 (43.75\%) are living in rural area. Most of the respondents, 40 (50\%) are having a monthly income of rupees $3001-6000,19(23.75 \%)$ are having a monthly income rupees $6001-10,000$ and $21(26.25 \%)$ are having a monthly income of rupees $\leq 3000.33$ (41.3\%) have primary education, 7 (8.75\%) have pre university/diploma education, $30(36.58 \%)$ have high school education where as $10(12.5 \%)$ doesn't have any formal education. Majority of the respondents, 47 (58.75\%) are married and $33(41.25 \%)$ are single. Majority of the participants, 29 (36.25\%) have an experience of 3.1 - 6 years, $8(10 \%)$ have an experience of $>9$ years, $23(26.75 \%)$ have an experience of 0 - 3 years and $20(25 \%)$ have 6.1 - 9 years of experience.

Most of the participants, 39 (48.75\%) have 8 working hours per day, 16 (20\%) have 12 working hours per day and $25(31.25 \%)$ have 10 working hours per day. Most of the participants, 40 (50\%) have 2 night shifts per week, 11 (13.75\%) have 4 weekly night shifts and 29 (36.25\%) have 3 weekly night shifts. Most of the respondents, $55(68.75 \%)$ doesn't have any previous history of illness and 25 (31.25\%) have diseases like Hypertension and Diabetes Table 1. 
Table 1. Frequency and percentage distribution of subjects on selected demographic variables.

\begin{tabular}{|c|c|c|c|}
\hline S1 No. & Demographic Variables & Frequency (f) & Percentage (\%) \\
\hline \multirow[t]{5}{*}{1} & Age in years & & \\
\hline & a) $20-29$ & 9 & 11.2 \\
\hline & b) $30-39$ & 33 & 41.3 \\
\hline & c) $40-49$ & 30 & 37.5 \\
\hline & d) $\geq 50$ & 8 & 10 \\
\hline \multirow[t]{3}{*}{2.} & Gender & & \\
\hline & a) Male & 54 & 67.5 \\
\hline & b) Female & 26 & 32.5 \\
\hline \multirow[t]{5}{*}{3.} & Religion & & \\
\hline & a) Hindu & 30 & 37.5 \\
\hline & b) Muslim & 17 & 21.3 \\
\hline & c) Christian & 33 & 41.2 \\
\hline & d) Others & 0 & 0 \\
\hline \multirow[t]{3}{*}{4.} & Area of living & & \\
\hline & a) Urban & 45 & 56.25 \\
\hline & b) Rural & 35 & 43.75 \\
\hline \multirow[t]{5}{*}{5.} & Monthly Income (in rupees) & & \\
\hline & a) $\leq 3000$ & 21 & 26.25 \\
\hline & b) $3001-6000$ & 40 & 50 \\
\hline & c) $6001-10000$ & 19 & 23.75 \\
\hline & d) $>10000$ & 0 & 0 \\
\hline \multirow[t]{6}{*}{6.} & Educational status & & \\
\hline & a) No formal education & 10 & 12.5 \\
\hline & b) Primary education $\left(1^{\text {st }}-7^{\text {th }} \mathrm{std}\right)$ & 33 & 41.25 \\
\hline & c) High school $\left(8^{\text {th }}-10^{\text {th }} \mathrm{std}\right)$ & 30 & 36.58 \\
\hline & d) Pre university/diploma & 7 & 8.75 \\
\hline & e) Graduation & 0 & 0 \\
\hline \multirow[t]{6}{*}{7.} & Marital status & & \\
\hline & a) Single & 33 & 41.25 \\
\hline & b) Married & 47 & 58.75 \\
\hline & c) Married and separately living & 0 & 0 \\
\hline & d) Divorced & 0 & 0 \\
\hline & e) Widow/widower & 0 & 0 \\
\hline \multirow[t]{5}{*}{8.} & Years of experience & & \\
\hline & a) $0-3$ & 23 & 28.75 \\
\hline & b) $3.1-6$ & 29 & 36.25 \\
\hline & c) $6.1-9$ & 20 & 25 \\
\hline & d) $>9$ & 8 & 10 \\
\hline
\end{tabular}




\section{Continued}

9. Number of working hours per day

$\begin{array}{lcc}\text { a) } 8 & 39 & 48.75 \\ \text { b) } 10 & 25 & 31.25 \\ \text { c) } 12 & 16 & 20 \\ \text { d) }>12 & 0 & 0\end{array}$

10. Number of night shifts per week

$\begin{array}{lcc}\text { a) } 2 & 40 & 50 \\ \text { b) } 3 & 29 & 36.25 \\ \text { c) } 4 & 11 & 13.75 \\ \text { d) }>4 & 0 & 0\end{array}$

11. Any previous history of illness

$\begin{array}{lll}\text { a) yes } & 39 & 48.75 \\ \text { b) No } & 55 & 68.75\end{array}$

Level of occupational stress showed that 59 security guards (73.75\%) are under moderate level of occupational stress, $21(26.25 \%)$ are under severe level of occupational stress and none of them are having mild level of occupational stress Table 2.

Knowledge regarding occupational stress and its management before the administration of Planned reaching programme shows that the majority of the sample 66 (82.5\%) had inadequate knowledge and 14 (17.5\%) of them had moderately adequate knowledge and none of them had adequate knowledge. Table 3

Area wise mean, standard deviation and mean percentage scores among the samples in the pre-test show that in area of general aspects and causes of occupational stress, the pre-test mean percentage was 30 with a mean and standard deviation of $1.5 \pm 0.62$. In area of prevention and management of occupational stress, mean percentage was 25.6 with a mean and standard deviation of $6.39 \pm$ 1.9. In the effects of occupational stress mean percentage was 29 with a mean and standard deviation of $2.18 \pm 0.65$ (Table 4).

Post-test results revealed that majority of the samples 67 (83.7\%) had adequate knowledge and 13 (16.3\%) of them had moderately adequate knowledge regarding occupational stress and its management (Table 5).

Mean, SD and " $\mathrm{t}$ " value showing the difference between mean pre-test and post-test level of knowledge, showed that mean post-test score (22.86) is higher than the pre-test knowledge score (10.06). The calculated pared $\mathrm{t}$ test value $(\mathrm{t}=$ $41.8)$ is greater than the table value $(t 79=1.664)$ at 0.05 level of significance shows that there is significant difference between the pre-test and post-test knowledge score. So planned teaching programme was found to be effective in improving level of knowledge regarding occupational stress and its management among security guards of a selected organization (Table 6).

Association between level of occupational stress and demographic variables 
Table 2. Frequency and percentage distribution of samples according to their level of occupational stress $(\mathrm{N}=80)$.

\begin{tabular}{cccc}
\hline Sl No. & Level of occupational stress & Frequency (f) & Percentage (\%) \\
\hline 1. & Mild & 0 & 0 \\
2. & Moderate & 59 & 73.7 \\
3. & Severe & 21 & 26.3 \\
\hline
\end{tabular}

Table 3. Frequency and percentage distribution of samples according to their level of knowledge before the administration of PTP $(\mathrm{N}=80)$.

\begin{tabular}{cccc}
\hline S1 No. & Level of occupational stress & Frequency (f) & Percentage (\%) \\
\hline 1. & Inadequate & 66 & 82.5 \\
2. & Moderately adequate & 14 & 17.5 \\
3. & Adequate & 0 & 0 \\
\hline
\end{tabular}

Table 4. Area wise mean, standard deviation and mean percentage scores among the samples in the pre-test.

\begin{tabular}{cccccc}
\hline S1 No. & Area & $\begin{array}{c}\text { Maximum } \\
\text { possible score }\end{array}$ & Mean & $\begin{array}{c}\text { Standard } \\
\text { Deviation }\end{array}$ & $\begin{array}{c}\text { Mean } \\
\text { percentage }\end{array}$ \\
\hline I $\quad \begin{array}{c}\text { Questions related to general aspects } \\
\text { and causes of occupational stress. }\end{array}$ & 4 & 1.5 & 0.62 & 30 \\
II $\quad \begin{array}{c}\text { Questions related to the effects of } \\
\text { occupational stress. }\end{array}$ & 6 & 2.18 & 0.65 & 29 \\
III $\quad \begin{array}{l}\text { Questions related to prevention and } \\
\text { management of occupational stress. }\end{array}$ & 20 & 6.39 & 1.9 & 25.6 \\
$\quad$ Total & 30 & 10.06 & 2.36 & 26.83 \\
\hline
\end{tabular}

Table 5. Frequency and mean percentage distribution of samples according to their pre-test and post-test level of knowledge $(\mathrm{N}=80)$.

\begin{tabular}{cccccc}
\hline \multirow{2}{*}{ S1 No. } & \multirow{2}{*}{ Level of Knowledge } & \multicolumn{2}{c}{ Pre test } & \multicolumn{2}{c}{ Post test } \\
\cline { 3 - 6 } & Frequency (f) & Percentage (\%) & Frequency (f) & Percentage (\%) \\
\hline 1. & Inadequate & 66 & 82.5 & - & - \\
2. & Moderately adequate & 14 & 17.5 & 13 & 16.3 \\
3. & Adequate & - & - & 67 & 83.7 \\
\hline
\end{tabular}

Table 6. Mean, SD and " $\mathrm{t}$ " value showing the difference between mean pre-test and post-test level of knowledge $(\mathrm{N}=80)$.

\begin{tabular}{ccccc}
\hline Sl No. & Variables & Mean & S.D & t value \\
\hline 1. & Pre test & 10.06 & 2.36 & $41.8^{\star}$ \\
2. & Post test & 22.86 & 2.65 & \\
\hline
\end{tabular}

$\mathrm{t}_{79}=1.66, \mathrm{p}<0.05,{ }^{*}$ Significant.

reveals that there is a significant association between number of night shifts and occupational stress $\left(\chi^{2}=12.32, \mathrm{p}<0.05\right)$, and no association between the other 
selected demographic variables and the level of occupational stress (Table 7).

Association between the pre test level of knowledge and selected demographic variables reveals that there is no association between the pre-test level of knowledge score and demographic variables of the security guards, Hence, there is no significant association between the level of pre test knowledge score and selected demographic variables at 0.05 level of significance (Table 8).

Table 7. Association between levels of occupational stress and demographic variables ( $\mathrm{N}$ $=80$ ).

Sl No. Demographic variables $\quad \leq$ median (9) $>$ median (9) $\chi^{2}$ value $\begin{gathered}\text { Level of } \\ \text { significant }\end{gathered}$

1 Age in years
a) $20-29$
b) 30 - 39
c) $40-49$
d) 50 - above

3
27
24
5

2 Gender

$\begin{array}{lcccc}\text { a) Male } & 42 & 12 & 1.39 & \text { NS } \\ \text { b) Female } & 17 & 9 & & \end{array}$

3 Religion

$\begin{array}{lllll}\text { a) Hindu } & 23 & 7 & & \\ \text { b) Muslim } & 10 & 7 & 2.49 & \text { NS } \\ \text { c) Christian } & 26 & 7 & & \\ \text { d) Other specify } & & & & \end{array}$

4 Area of living

$\begin{array}{lcccc}\text { a) Urban } & 36 & 9 & 2.08 & \text { NS } \\ \text { b) Rural } & 23 & 12 & & \end{array}$

5 Monthly income (in rupees)
a) $\leq 3000$
b) $3001-6000$
c) $6001-10,000$
d) $\geq 10,001$

6 Educational status

$\begin{array}{lcccc}\text { a) No formal education } & 7 & 3 & & \\ \text { b) Primary education } & 27 & 6 & & \\ \text { c) High school } & 23 & 7 & 1.36 & \text { NS } \\ \text { d) PUC/Diploma } & 2 & 5 & & \\ \text { e) Graduation } & & & & \end{array}$

7 Marital status
a) Single
22
11
$1.5 \quad$ NS
b) Married
37
10 


\section{Continued}

c) Married and separately living

d) Divorced

e) Widow/widower

8 Years of experience
a) 0 - 3
17
b) $3.1-6$
23
NS
c) 6.1 - 9
d) Above 9
14
$5-3$

9 Number of working hours per day
a) 8
b) 10
32
7
c) 12
19
7
2.71
NS
d) Above 12

10 Number of night shifts per week
a) 2
$36-4$
b) 3
c) 4
31
8
12.32
${ }^{*} S$
d) Above 4

11 Any previous history of illness
a) Yes
15
10
3.55
NS
b) No
44
11

NS $=$ Not significant, $\chi^{2}(3)=5.991, p<0.05,{ }^{*}$ Significant.

Table 8. Association between the levels of Knowledge and selected demographic variables $(\mathrm{N}=80)$.

\begin{tabular}{|c|c|c|c|c|c|}
\hline Sl No. & Demographic variables & $\leq$ median (50) & $>$ median (50) & $\begin{array}{l}\text { Chi-square } \\
\text { value }\end{array}$ & $\begin{array}{l}\text { Level of } \\
\text { significant }\end{array}$ \\
\hline \multirow[t]{5}{*}{1} & Age in years & & & & \\
\hline & a) $20-29$ & 1 & 8 & & \\
\hline & b) $30-39$ & 24 & 9 & 0.04 & NS \\
\hline & c) $40-49$ & 14 & 16 & & \\
\hline & d) 50 - above & 2 & 6 & & \\
\hline \multirow[t]{3}{*}{2} & Gender & & & & \\
\hline & a) Male & 35 & 19 & & \\
\hline & b) Female & 6 & 20 & 2.89 & NS \\
\hline \multirow[t]{5}{*}{3} & Religion & & & & \\
\hline & a) Hindu & 17 & 13 & & \\
\hline & b) Muslim & 4 & 13 & 0.02 & NS \\
\hline & c) Christian & 20 & 13 & & \\
\hline & d) Other specify & - & - & & \\
\hline
\end{tabular}




\section{Continued}

\section{$4 \quad$ Area of living}

$\begin{array}{lllll}\text { a) Urban } & 25 & 20 & 0.23 & \text { NS } \\ \text { b) Rural } & 16 & 19 & & \end{array}$

5 Monthly income (in rupees)

$\begin{array}{lcc}\text { a) } \leq 3000 & 7 & 15 \\ \text { b) } 3001-6000 & 31 & 13 \\ \text { c) } 6001-10,000 & 3 & 11 \\ \text { d) } \geq 10,001 & - & \end{array}$

6 Educational status

$\begin{array}{lcccc}\text { a) No formal education } & 2 & 8 & & \\ \text { b) Primary education } & 9 & 14 & & \\ \text { c) High school } & 20 & 10 & 0.23 & \text { NS } \\ \text { d) PUC/Diploma } & 0 & 7 & & \\ \text { e) Graduation } & - & - & & \end{array}$

$7 \quad$ Marital status
a) Single
b) Married
c) Married and separately living
d) Divorced
e) Widow/widower

13

20

1.76

NS

28

8 Years of experience
a) 0 - 3
b) 3.1 - 6
c) $6.1-9$
d) Above 9

9 Number of working hours per day
a) 8

$32 \quad 16$
b) 10
c) 12
$12-13$

d) Above 12

10 Number of night shifts per week
a) 2
22
b) 3
17
c) 4
d) Above 4

11 Any previous history of illness

\begin{tabular}{lcccc} 
a) Yes & 5 & 20 & 2.77 & NS \\
b) No & 36 & 19 & & \\
\hline
\end{tabular}

NS $=$ Not significant 


\section{Discussion}

\section{Section I: Description of demographic data}

The majority of samples that is $33(41.3 \%)$ are in the age group of $30-39$ years, $8(10 \%)$ are in the age group of $\geq 50$ years, 30 (37.5\%) are in the age group of 40 - 49 years, and $9(11.2 \%)$ are in the age group of 20 - 29. Based on Gender classification, majority of the samples that is, $54(67.5 \%)$ were men and 26 (32.5\%) were women in the study. Most of the samples 33 (41.2\%) belonged to the Christian community, 17 (21.3\%) were from the Muslim community and 30 (37.5\%) belonged to the Hindu community.

Majority of the samples 45 (56.25\%) are living in urban area and 35 (43.75\%) are living in rural area. Most of the respondents, 40 (50\%) are having a monthly income of rupees $3001-6000,19(23.75 \%)$ are having a monthly income rupees $6001-10,000$ and $21(26.25 \%)$ are having a monthly income of rupees $\leq 3000.33$ (41.3\%) have primary education, 7 (8.75\%) have pre university/diploma education, $30(36.58 \%)$ have high school education where as $10(12.5 \%)$ doesn't have any formal education. Majority of the respondents, 47 (58.75\%) are married and 33 (41.25\%) are single. Majority of the participants, 29 (36.25\%) have an experience of 3.1 - 6 years, 8 (10\%) have an experience of $>9$ years, $23(26.75 \%)$ have an experience of 0 - 3 years and $20(25 \%)$ have 6.1 - 9 years of experience.

Most of the participants, 39 (48.75\%) have 8 working hours per day, 16 (20\%) have 12 working hours per day and $25(31.25 \%)$ have 10 working hours per day. Most of the participants, 40 (50\%) have 2 night shifts per week, $11(13.75 \%)$ have 4 weekly night shifts and 29 (36.25\%) have 3 weekly night shifts. Most of the respondents, $55(68.75 \%)$ doesn't have any previous history of illness and 25 (31.25\%) have diseases like Hypertension and Diabetes.

\section{Section II: Assessment of level of occupational stress}

In the present study occupational stress score showed that the majority of the security guards that is $59(73.7 \%)$ were under moderate level of occupational stress and $21(26.3 \%)$ were under severe level of occupational stress. None of them experienced mild level of occupational stress.

The findings of the present study were consistent with a descriptive study done in Shanghai, China among 527 nurses from 41 hospitals to assess the occupational burnout and its association with occupational stress. Results showed that most of the nurses, that is $74.76 \%$ were affected with moderate level of occupational stress and are very prone to have occupational burnout, $27.13 \%$ were having severe level of occupational stress which was strongly associated with work-related stress. Interventions in reducing occupational stress are needed to reduce the burden of burnout in Chinese nurses [12].

\section{Section III: Pre test level of knowledge}

In the present study the pre-interventional score showed that the majority of the samples 66 (82.5\%) had inadequate knowledge regarding occupational stress and its management before the administration of PTP, 14 (17.5\%) of them had moderately adequate knowledge and none of them had adequate knowledge. 
The findings of the present study were consistent with a descriptive survey conducted in Poland, among 210 employees to assess their knowledge regarding sources and consequences of work stress. Stressors intrinsic to the job (mostly work overload) were recognized as best known to employees (67.62\%). The second place was occupied by stressors originating from interpersonal relationships at work (51.9\% of respondents pointed out that problem). Almost no one $(0.48 \%)$ mentioned home-work interference as a source of occupational stress. According to the respondents' opinion, occupational stress mostly results in health decline. The employees who participated in the study believe that the employer $(13.81 \%)$ or the superior $(19.05 \%)$ is responsible for psychosocial risks prevention at the work place. Almost a half of subjects (46.67\%) did not know whether there are any law regulations on psychosocial risk at work in Poland. The study concluded that the respondents showed an average level of knowledge of psychosocial risk at the work place and knew almost nothing about occupational stress prevention. The results of the study point to the need for systematic education of employees about stress and stress related issues [13].

\section{Section IV: Evaluation of effectiveness of PTP}

The findings of the present study showed that overall post-test mean percentage is $63.53 \%$ with a mean of $22.86 \pm 2.65$ which is higher compared to mean percentage $(26.83 \%)$ and mean and standard deviation $(10.06 \pm 2.36)$ of the pre test. The data also shows that the maximum gain that is $37.5 \%$ occurred in the area of general aspects and causes of occupational stress and minimum gain, that is $35 \%$ occurred in effects of occupational stress. The mean post-test score (22.86) is higher than the pre-test knowledge score (10.06). The calculated $t^{\prime}$ value $(\mathrm{t} 79=37.11)$ is greater than the table value $(\mathrm{t} 79=1.664)$ at 0.05 level of significance shows that there is significant difference between the pre-test and post-test knowledge score.

The findings of the present study were consistent with a randomized control trial done among 46 supervisors to find out the effectiveness of education programme on stress reduction in Japan. Experimental group consisted of 24 and control group consisted of 22 supervisors respectively. A single-session education program that included the guidelines for worker mental health promotion was given to the intervention group. The education program was composed of a basic education lecture and active listening training. The education favorably affected supervisor knowledge $(F=7.92 ; \mathrm{p}=0.001)$. As for behavior, the intervention effect was marginally statistically significant $(\mathrm{F}=2.51 ; \mathrm{p}=$ 0.088 ). In conclusion, the provision of necessary information and useful skills to supervisors seems to improve supervisor knowledge and behavior regarding stress management at the workplace for at least six months [14].

Section V: Association between the level of occupational stress and selected demographic variables

The study findings revealed that there is a significant association between number of night shifts and level of occupational stress $\left(\chi^{2}=12.32\right)$ at 0.05 level of significance. Other demographic variables didn't show any association with 
the level of occupational stress at 0.05 level of significance.

The findings of the present study were consistent with a cross sectional study conducted in China among 2613 nurses from 20 hospitals to assess the job stress perceived by them. The study findings showed that Mean Personal Strain Questionnaire score was 86.9. There was a significant association between the stress score with role insufficiency, responsibility and night shifts. The study concluded that Occupational health education and occupational training programmes may be necessary to improve the knowledge and ability of nurses to cope with job demands and reduce occupational stress [15].

Section VI: Association between the level of knowledge and selected demographic variables

The study findings revealed that there is no significant association between pre interventional knowledge score and selected demographic variables.

\section{Conclusions}

The results were explained by using descriptive and inferential statistics. The following conclusions were drawn on the basis of the findings of the study:

1) The occupational stress assessment findings revealed that the majority of the participants, 59 (73.7\%) were under a moderate level of occupational stress and 21 (26.3\%) were under a severe level of occupational stress.

2) The pre test findings revealed that the majority of the subjects, 66 (82.5\%) had an inadequate level of knowledge regarding occupational stress and its management and remaining, 14 (17.5\%) had a moderately adequate level of knowledge and none of them had an adequate level of knowledge. The post test results had shown that 67 subjects (83.7\%) gained adequate knowledge and remaining 13 (16.3\%) had moderately adequate knowledge.

3) Following the administration of planned teaching programme, there was a significant gain in mean post test knowledge score (22.86) compared to that of mean pre-test knowledge scores (10.06). This indicates that teaching programme was effective in increasing the knowledge of security guards regarding occupational stress and its management.

4) It was found that there was a significant association between the number of night shifts and level of occupational stress and no association was found between other demographic variables and level of occupational stress.

5) It was also found that there was no significant association between the demographic variables and pre-test knowledge scores.

\section{Conflicts of Interest}

The authors declare no conflicts of interest regarding the publication of this paper.

\section{References}

[1] Wikipedia, the Free Encyclopedia [Internet]. Stress (Biology). 
http://en.wikipedia.org/wiki/Stress (medicine)

[2] Causes behind Stress at Workplace.

https://www.selfgrowth.com/articles/causes behind stress at workplace

[3] Occupational Stress and Coping among Irish Prison Officers: An Exploratory Examination Sinead Regan MSc. Occupational Stress and Coping among Prison Officers, Sinead Regan.

https://cscsproject.weebly.com/uploads/1/3/7/1/1371292/regan 2009 full thesis.pdf

[4] Suryanarayan, D. (2009) Survey Finds 57\% Rise in Work-Related Stress in India. Dnaindia (Internet).

http://www.dnaindia.com/mumbai/report survey-finds-57pct-rise-in-work-relatedstress-in-india 1318201

[5] Henry, O. and Evans, A.J. (2008) Occupational Stress in Organizations. Journal of Management Research, 8, 123-135.

[6] Sripichyakan, K., Thungpunkum, P. and Supavititpatana, B. (2003) Work Place Violence in the Health Sector: A Case Study in Thailand. Joint Programme on Work Place Violence in Health Sector. 1-31.

[7] Agolla, O.H. (2008) Occupational Stress in Organizations and Its Effects on Organizational Performance. Journal of Management Research, 8, 123-135.

[8] Al Khalidi, D. and Wazaify, M. (2013) Assessment of Pharmacists' Job Satisfaction and Job Related Stress in Amman. International Journal of Clinical Pharmacy, 35, 821-828. https://doi.org/10.1007/s11096-013-9815-7

[9] Brown, S.C. (2005) Investigating Stress in Security Guards on the University of Witwatersrand, Johanesberg. 16-83. http://wiredspace.wits.ac.za/handle/10539/1479

[10] Heron, R.J., Mckeown, S., Tomenson, J.A. and Teasdale, E.L. (1999) Study to Evaluate the Effectiveness of Stress Management Workshops on Response to General and Occupational Measures of Stress. Occupational Medicine, 49, 451-457. https://doi.org/10.1093/occmed/49.7.451

[11] Hase, Y., Hori, H., Nakaysu, I., Masushita, Y., Inagaki, M., Unno, A., et al. (2008) Approach to Easing Occupational Stress for High Stress Workers: Applying the Brief Job Stress Questionnaire to Workplace Mental Health Promotion. Sangyo Eiseigaku Zasshi, 50, 111-119. https://doi.org/10.1539/sangyoeisei.B7010

[12] Xie, Z., Wang, A. and Chen, B. (2011) Nurse Burnout and Its Association with Occupational Stress in a Cross-Sectional Study in Shanghai. Journal of Advanced Nursing, 67, 1537-1546. https://doi.org/10.1111/j.1365-2648.2010.05576.x

[13] Potocka, A. and Merecz-Kot, D. (2010) What Do We Know about Psychosocial Risks at Work? Part II. The Analysis of Employee's Knowledge of Sources and Consequences of Stress at Work. Medycyna Pracy, 61, 393-411.

[14] Nishiuchi, K., Tsutsumi, A., Takao, S., Mineyama, S. and Kawakami, N. (2007) Effects of an Education Program for Stress Reduction on Supervisor Knowledge, Attitudes, and Behavior in the Workplace: A Randomized Controlled Trial. Journal of Occupational Health, 49, 190-198. https://doi.org/10.1539/joh.49.190

[15] Wu, H., Chi, T.S., Chen, L., Wang, L. and Jin, Y.P. (2010) Occupational Stress among Hospital Nurses: Cross-Sectional Survey. Journal of Advanced Nursing, 66, 627-634. https://doi.org/10.1111/j.1365-2648.2009.05203.x 